\title{
Descriptions of Two Digenean Trematodes Found from a Chinese Sea Snake, Laticauda semifasciata, in Republic of Korea
}

\author{
Seongjun Choe ${ }^{1}$, II-Hun Kim², Min-Seop Kim², Hae Rim Lee ${ }^{3}$, Youngjun Kim³, Keeseon S. Eom,* \\ 'Department of Parasitology, School of Medicine and Parasite Research Center, Chungbuk National University, Cheongju 28644, Korea; \\ ${ }^{2}$ National Marine Biodiversity Institute of Korea, Seocheon 33662, Korea; ${ }^{3}$ National Institute of Ecology, Seocheon 33657, Korea
}

\begin{abstract}
We intended to describe 2 digenean trematodes found from a Chinese sea snake, Laticauda semifasciata, as the new fauna in the Republic of Korea. The snake was caught offshore of Aewol-eup, Jeju-do, in August 2017. Two species of fluke were found in the lung and intestinal tract of the snake in the process of necropsy. They were identified as Pulmovermis cyanovitellosus Coil and Kuntz, 1960 and Harmotrema laticaudae Yamaguti, 1933, respectively based on the morphological characters. Pulmovermis cyanovitellosus showed elongated body with well-developed and elongated male genital system and compact vitelline. And $H$. laticaudae was characterized by linguiform body with heavily armed cirrus with excretory system. This is the first time both species have been reported and described off the Korean coast. We provide morphological descriptions with some comments on their biology and geographical distribution. In addition, the taxonomic validity of the genus Hydrophitrema Sandars, 1960 was discussed, in terms of morphological descriptions and host ranges. This study provides novel insight into digenean fluke species existing off the coast of Korea.
\end{abstract}

Key words: Laticauda semifasciata, Pulmovermis cyanovitellosus, Harmotrema laticaudae, Chinese sea snake

\section{INTRODUCTION}

Sea snakes, also referred to as marine snakes, are a group of snakes that are fully adapted to underwater life and live in marine environments. They have flattened, paddle-like tails with advanced diving ability and/or have laterally compressed bodies adapted for their aquatic life. Generally, sea snakes are classified into 2 subfamilies called Hydrophiinae (true sea snakes) and Laticaudinae (sea kraits). They are widely recognized as having diverged and evolved from terrestrial elapid snakes [1-5].

Laticauda semifasciata (Reptila: Elapidae), also known as Chinese sea snake or black-banded sea krait, is a species that has which recently been added to the Korean herpetofauna list [6]. In the past, Chinese sea snake has been known to inhabit the tropical and subtropical regions of China, Japan, Philippines, and Taiwan [7]. However, recent studies have shown that the snakes are increasingly found outside their original habitats to the north, including the Republic of Korea (Korea), Russia,

\footnotetext{
- Received 6 December 2019, revised 14 May 2020, accepted 19 May 2020

*Corresponding author (kseom@chungbuk.ac.kr)

(C) 2020, Korean Society for Parasitology and Tropical Medicine

This is an Open Access article distributed under the terms of the Creative Commons Attribution Non-Commercial License (https://creativecommons.org/licenses/by-nc/4.0) which permits unrestricted non-commercial use, distribution, and reproduction in any medium, provided the original work is properly cited.
}

and the mainland of Japan [6,8-10].

The digenean flukes of $L$. semifasciata have previously only been investigated in their original habitats. Coil and Kuntz [11] 1960 reported 2 species of digenean flukes, i.e., Ateuchocephala marinus Coil \& Kuntz, 1960 and Pulmovermis cyanovitellosus Coil \& Kuntz, 1960, from Orchid Island (Lan Yu Isl.), Taiwan. In 1967, Telford examined 51 L. semifasciata specimens obtained from Amami Island, Japan, and found 2 distinct species of digenean parasites, namely P. cyanovitellosus and Harmotrema laticaudae Yamaguti, 1933 [12]. More recently, Ohashi et al. [13] recorded P. cyanovitellosus from Kudakajima Island, Japan. However, the digenean flukes of L. semifasciata in Korea have not been investigated to date.

Recently, we had the opportunity to examine a Chinese sea snake, L. semifasciata, collected from Korean waters, offshore of Jeju Island, and found 2 species of digenean flukes, H. laticaudae Yamaguti, 1933 (Digenea: Liolopidae) and P. cyanovitellosus Coil and Kuntz, 1960 (Digenea: Hemiuridae) for the first time in Korea. The aim of present study is to provide morphological descriptions with taxonomical and ecological comments on the 2 newly recorded species in Korea. 


\section{MATERIALS AND METHODS}

A Chinese sea snake, L. semifasciata was offered for necropsy to a veterinary clinic at the National Institute of Ecology, Seocheon, Korea on December 11, 2017. The snake was initially caught and donated by local fisherman to the National Marine Biodiversity Institute of Korea (MABIK) for sea snake research, but died while rearing in captivity. It was caught offshore of Aewol-eup, Jeju-do, Korea $\left(33^{\circ} 28^{\prime} 38^{\prime \prime} \mathrm{N}, 126^{\circ} 18^{\prime} 46^{\prime \prime} \mathrm{E}\right)$ on August 11, 2017. Upon physical examination, the snake (Code no. LS-KJ 11) was male, measured $117.6 \mathrm{~cm}$ long (snout to vent-length) with a weight of $966.5 \mathrm{~g}$. It was equipped with the morphological characteristics of L. semifasciata [6]. During the rearing in captivity, it was fed Korean sand lance, Hypoptychus dybowskii Steindachnerm 1880 (stored frozen) every 2 weeks, and the temperature of the water tank was maintained at approximately $23^{\circ} \mathrm{C}\left( \pm 2^{\circ} \mathrm{C}\right)$. The snake died 3 months after its capture.

During the necropsy, noteworthy lesions were not observed except for the lumen of the lungs. Lung lobes showed bloody foamy exudates, around which 21 reddish elongated flukes were found (Fig. 1). And 5 small tongue-shaped flukes were found from the intestine. They were washed in $0.9 \%$ saline and then transferred into $70 \%$ ethyl alcohol or 10\% neutralbuffered formalin for further molecular and morphological studies.

The specimens for morphological observation were examined following staining with Semichon's acetocarmine solution, dehydrated using graded alcohol series, cleared in xylene, and mounted permanently in Permount (Fisher Scientific).

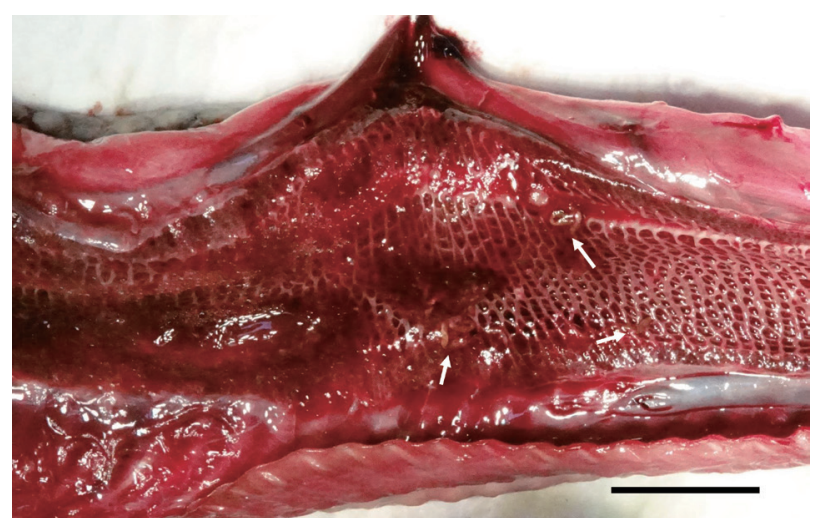

Fig. 1. Gross lesion of a lung in a Chinese sea snake from the Republic of Korea. The lung lesion showing foamy bloody exudate with elongated parasites, Pulmovermis semifasciata (arrows). Scale bar $=2 \mathrm{~cm}$.
Observations were conducted under a light microscope (Olympus BX-53, Tokyo, Japan). The drawings were made using the microscope, which was equipped with a DIC system and drawing tube. Measurements were taken and calculated from drawings. Some measurements were cross-checked by comparison with measurements using a micrometer equipped on the eyepiece of light microscope.
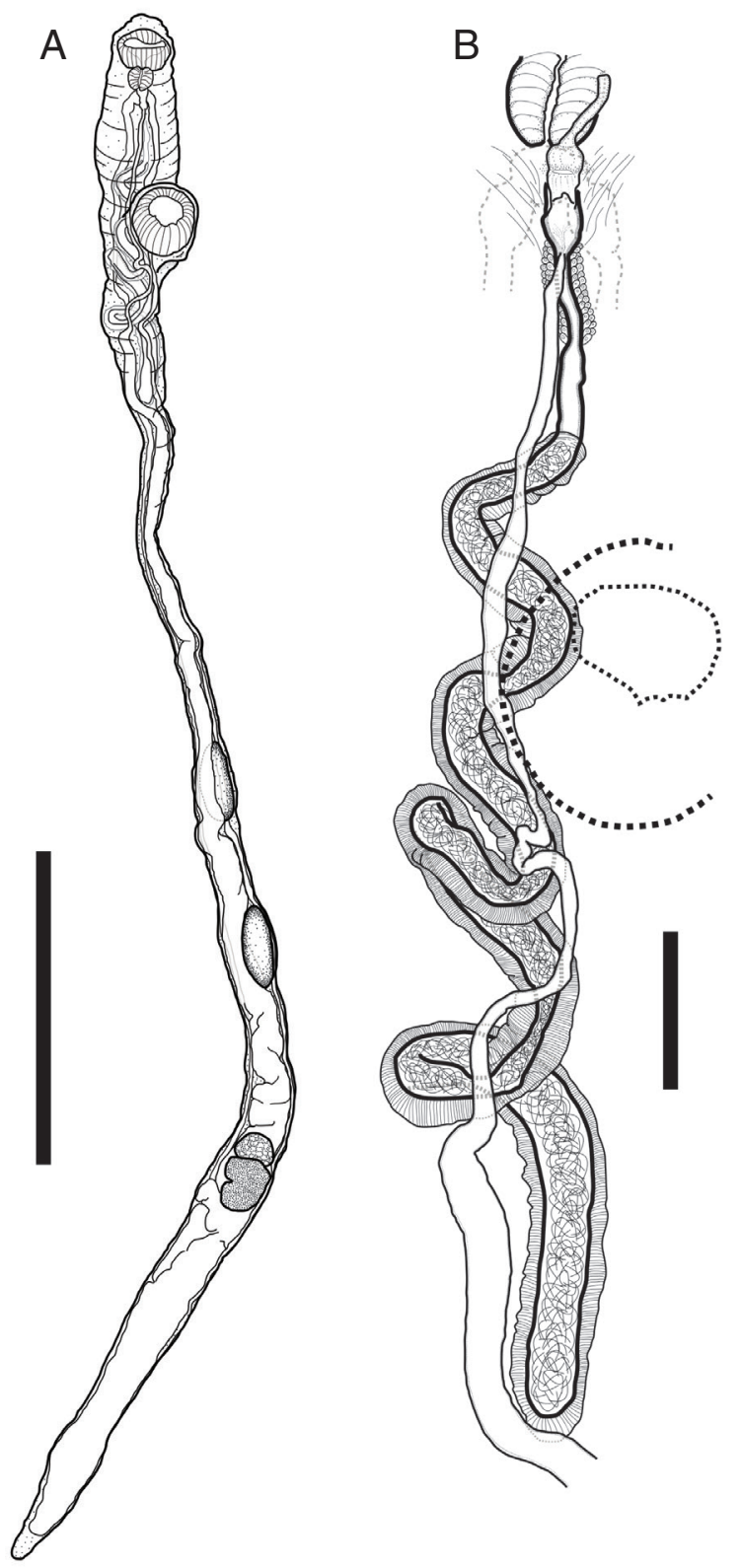

Fig. 2. Pulmovermis cyanovitellosus, drawings of adult worm found from a Chinese sea snake Laticauda semifasciata. (A) Entire worm. (B) Terminal genitalia. Scale bar: (A) 4 mm; (B) 500 um. 


\section{RESULTS}

\section{Pulmovermis cyanovitellosus Coil \& Kuntz, 1960}

Description of worms was based on 4 fully mature worms as whole-mounted specimens (Fig. 2). Measurements are shown in Table 1. Body large, elongate, cylindrical, with maximum width at anterior to ventral sucker or posterior to ovary. Thinnest between ventral sucker and anterior testis when it stretched. Forebody very short. Ecsoma reduced. Body surface smooth or covered with small papillae.

Oral sucker well-developed, subglobular, muscular, subterminal. Pharynx melon-shaped, well-developed, muscular. Prepharynx and oesophagus absent. Ventral sucker muscular, subglobular, with deep cavity, slightly larger than oral sucker, project to somewhat ventrally, located close to anterior extremity. Intestinal bifurcation at level of pharynx; caeca blind, connect somewhat anterior, and then extend along each side of body to posterior extremity.

Testes two, tandem, elongate-oval, smooth, separated, located in third quarter of body. Seminal vesicle tubular, very long, surrounded by thick muscular walls. Genital pore posterior to pharynx. Cirrus short tubular. Ovary subspherical, locat- ed in posterior quarter of body. Vitellarium posterior to ovary, divided into 7 unnoticed lobes. Uterus tubular, filled with numerous eggs, extensively located in posterior part of body, connected along bodyline to genital pore linearly. Eggs very small.

\section{Harmotrema laticaudae Yamaguti, 1933}

Description of worms was based on 4 fully mature worms as whole-mounted specimens (Fig. 3). Measurements are shown in Table 2. Body tongue-shaped, elongate, with blunt to round anterior and posterior extremity, maximum width at level of cirrus sac. Forebody short. Body surface smooth.

Oral sucker spherical, terminal. Prepharynx absent or short, Pharynx muscular, similar with oral sucker in size. Oesophagus short. Intestinal bifurcation just somewhat behind to pharynx, caeca blind, extend along the line between lateral body line and median line to posterior extremity. Ventral sucker spherical, larger than oral sucker. located 20\% region from anterior extremity. Excretory system well-developed, paired inter- and extracaecal tubules united at anteriorly to intestinal bifurcation and posterior extremity.

Testes two, tandem. intercecal, distribute to third quarter of body, separated. Anterior testis located at midlevel of body,

Table 1. Morphometric comparison of Pulmovermis cyanovitellosus found from Chinese sea snake with those of previous studies (unit: $\mu$ m)

\begin{tabular}{|c|c|c|c|}
\hline Organ & Coil \& Kuntz, 1960 & Telford, 1967 & Present study (average) \\
\hline Body length & 17,000 & $10,900-21,300$ & $12,022-25,056(19,404)$ \\
\hline width, maximum & 1,200 & $800-1,620$ & $831-1,079(933)$ \\
\hline minimum & & & $180-427(262)$ \\
\hline Oral sucker length & $290-530$ & $530-710$ & $517-629(570)$ \\
\hline width & & $450-660$ & $562-685(612)$ \\
\hline Pharynx length & $200-300$ & $290-400$ & $258-315(284)$ \\
\hline width & & $230-340$ & $180-315(275)$ \\
\hline Seminal vesicle length & & & $3,258-5,978(4,736)$ \\
\hline Ventral sucker length & $440-730$ & $700-1,230$ & $652-921(781)$ \\
\hline width & & $680-1,180$ & $787-966(876)$ \\
\hline Anterior extremity to ventral sucker & & & $1,483-2,157(1,809)$ \\
\hline Anterior testis length & $580-970$ & $540-1,400$ & $562-1,011(848)$ \\
\hline width & & $350-620$ & 292-404 (337) \\
\hline Posterior testis length & & $1290-1,440$ & $472-1,191$ (938) \\
\hline width & & $350-660$ & $292-449$ (362) \\
\hline Distance between testes & & & $225-2,202(1,258)$ \\
\hline Ovary length & $530-900$ & $430-750$ & $270-427(340)$ \\
\hline width & & $420-740$ & 247-494 (357) \\
\hline Vitellaria length & $530-900$ & & $472-719(646)$ \\
\hline width & & & $292-584(421)$ \\
\hline Egg* length & $17-23$ & & $14-18(17)$ \\
\hline width & $10-12$ & & 7-9 (9) \\
\hline
\end{tabular}

${ }^{*} n=20$. 


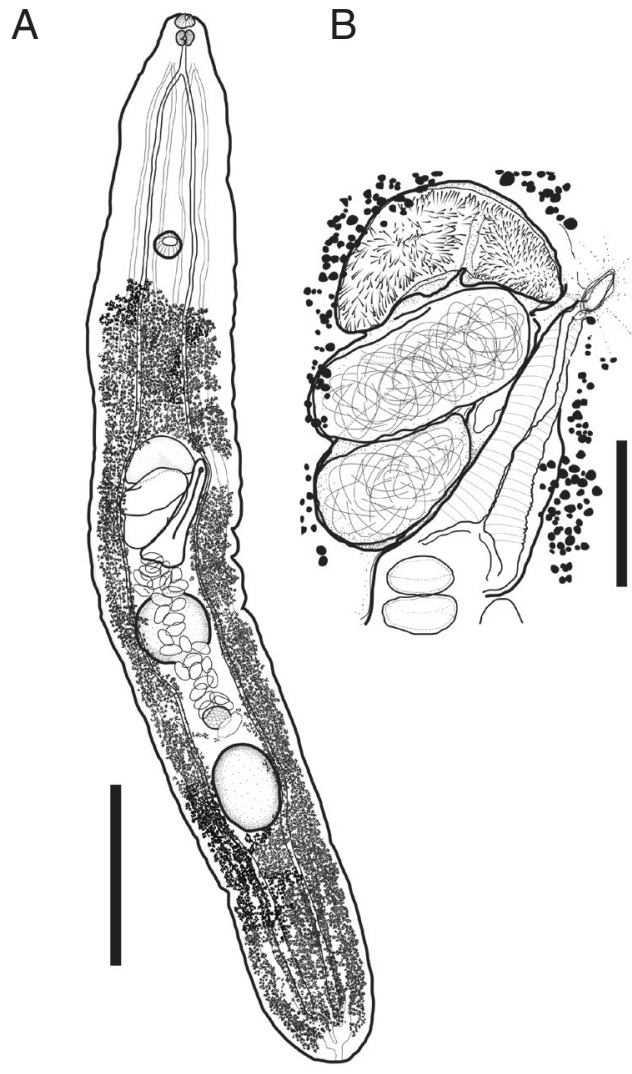

Fig. 3. Harmotrema laticaudae, drawings of adult worm found from a Chinese sea snake Laticauda semifasciata. (A) Entire worm. (B) Terminal genitalia. Scale bar=1 mm (A), $250 \mu \mathrm{m}$ (B).

spherical slightly broader. Posterior testis located at 1,582 $\mu \mathrm{m}$ away from posterior extremity, spherical. Cirrus sac large, slightly obliquely positioned, anterior to anterior testis. Genital pore sinistral, intercecal. Seminal vesicle bipartite, proximal part oval, distal part elongated, surrounded by prostatic cells. Ejaculatory duct and cirrus armed with minute spines.

Ovary located between 2 testes, oval, much smaller than testes. Vitelline follicles minutes, distribute from somewhat anteriorly to posterior extremity to posterior to ventral sucker. Uterus occurred at level of ovary, extend anteriorly to genital pore through ventral side of body, coiled, filled with eggs. Metraterm well-developed, composed by strong muscles, occupying posterosinistral region of cirrus sac. Eggs oval.

\section{DISCUSSION}

Sea snakes are typically found in the warm waters of tropical and subtropical seas belonging to the Indian and Pacific oceans. However, sea snakes have recently been found outside
Table 2. Morphometric comparison of Harmotrema laticaudae with original description (unit: $\mu \mathrm{m}$ )

\begin{tabular}{|c|c|c|}
\hline Organs & $\begin{array}{l}\text { Laticauda laticauda } \\
\text { Yamaguti, } 1933\end{array}$ & $\begin{array}{l}\text { Laticauda semifasciata } \\
\text { Present study (average) }\end{array}$ \\
\hline Body length & $5,700-6,900$ & $6,022-6,818(6,433)$ \\
\hline width & $1,000-2,000$ & $745-1,136(975)$ \\
\hline Oral sucker length & $75-100$ & 82-123 (91) \\
\hline width & $110-120$ & $109-141(117)$ \\
\hline Pharynx length & $90-110$ & $100-109$ (102) \\
\hline width & & $100-127(111)$ \\
\hline Prepharynx length & & $0-5$ \\
\hline Esophagus length & $40-80$ & $118-150(134)$ \\
\hline $\begin{array}{l}\text { Anterior end to intestinal } \\
\text { bifurcation }\end{array}$ & & 327-331 (330) \\
\hline Ventral sucker length & $110-130$ & $127-191(161)$ \\
\hline width & $110-175$ & $127-191(159)$ \\
\hline $\begin{array}{l}\text { Anterior extremity to } \\
\text { ventral sucker }\end{array}$ & & 1,209-1,309 (1,266) \\
\hline Cirrus sac length & & 600-664 (625) \\
\hline width & & $318-382(350)$ \\
\hline Seminal vesicle length & & $400-482(448)$ \\
\hline width & & $282-300(290)$ \\
\hline Metraterm length & & $518-691(586)$ \\
\hline width & & $209-300(255)$ \\
\hline Anterior testis length & $500-550$ & $382-509(455)$ \\
\hline width & $440-600$ & $382-436(411)$ \\
\hline Posterior testis length & $600-700$ & $473-573(511)$ \\
\hline width & $450-560$ & 350-382 (372) \\
\hline Distance between testes & & $0-745(477)$ \\
\hline Ovary length & $160-250$ & 136-209 (182) \\
\hline width & $230-310$ & $164-281(191)$ \\
\hline Egg* length & $123-129$ & $111-125(123)^{\star}$ \\
\hline width & $75-78$ & $59-77(68)^{\star}$ \\
\hline
\end{tabular}

${ }^{*} n=13$.

of their typical habitats. Recent reports indicate these out-of habitat findings have occurred on the mainland of Japan, the Russian Far East, and California, USA $[8,9,15]$. This phenomenon is believed to be the effect of global warming, and the increasing appearances of sea snakes in Korean waters are also thought to be due to the same reason [10]. Laticauda semifasciata is one of 2 sea snake species that was recently discovered in Korean waters $[6,14]$. The typical distribution is marine areas around China, Taiwan, the southern Islands of Japan, Philippines, and Indonesia [16]. Furthermore, the occurrences and observations of $L$. semifasciata in Korea have been increasing. Park et al. [10] analyzed the haplotype network using partial sequences of mitochondrial cytochrome b (Cytb) genes extracted from 12 L. semifasciata caught in Korean waters, and confirmed the northward dispersal of the species. However, the parasites of the sea snakes in Korean waters have not been 
investigated until the present study.

In this study, we identified 2 species of digenean flukes that have distinctly different morphological characteristics, from a Chinese sea snake that died in a breeding environment. We provided the morphological descriptions and measurements of these Korean isolates and compared them to previously reported cases. Morphological identification indicates the present specimens are digenean fluke species that have been reported before from same host species, L semifasciata. Based on morphological characteristics and morphometric analysis (Tables 1,2), the 2 species of digenean flukes were identified as $P$. cyanovitellosus, from the lungs, and $H$. laticaudae, from the intestines. Both of the morphology and measurements fit well with the previously recorded morphology and measurements of each species $[11,12,30]$. Information regarding the digenean flukes of sea snakes is scarcely reported. However, these 2 species have been recorded relatively frequently in areas such as Taiwan and Ryukyu Islands [11-13]. Considering these factors, the existence of the 2 species of digenean flukes in L. semifasciata was suspected to be related to the origin of its host.

The body shape of P. cyanovitellosus in the present study is noteworthy, and it highlights that further studies regarding the validity of the genus Hydrophitrema Sandars, 1960, and its only known species, H. giganticum Sandars, 1960 (also known as $H$. gigantica, emended after follows WoRMS [17]). The genus $\mathrm{Hy}$ drophitrema was determined based on 6 specimens obtained from the lungs of an elegant sea snake Hydrophis elegans (Gray, 1842) caught from Moreton Bay, Queensland, Australia just 2 days after the discovery of P. cyanovitellosus was published $[18,19]$. Sandars [19] observed specimens of both Pulmovermis and Hydrophitrema, and noted they are closely related, and it seemed likely the 2 genera were synonymous, but they can be accepted as 2 distinct genera based on several factors. Sandars [19] erected a subfamily (Pulmoverminae Sandars, 1961) and noted the first comparisons between Pulmovermis and $\mathrm{Hy}$ drophitrema. Vercammen-Grandjean and Heyneman (1964) corrected some erroneously recorded factors described by Sandars $(1960,1961)$, including the body size of $H$. giganticum (17-26 mm rather than $170-260 \mathrm{~mm}$ ) and the seminal vesicle to body length ratio (1:4.7 rather than 1:47), and suggested comparisons based on the corrected measurements of Sandars (1960), 2 types of specimens of $P$. cyanovitellosus, his own collection of $\mathrm{H}$. giganticum, and the drawings of the original paper [18-20]. According to their proposal, both genera can be distinguished mainly by the following factors: 1) general body shape (elongate tubular shape vs. elongate oblong shape), 2) the position and shape of the acetabulum, 3) the degree of seminal vesicle coiling, 4) the arrangement of the testes (tandem vs. oblique), and 5) the presence of tegumental folds or thickening enclosing both suckers in Hydrophitrema [20]. The validity of the genus Hydrophitrema was well-accepted by several authors until the 1970s [20-23]. However, after Gibson et al. [24] listed the genus Hydrophitrema as a junior synonym of genus Pulmovermis, the validity of the genus Hydrophitrema has been neglected and not been discussed further $[24,25]$. Furthermore, $H$. giganticum was also regarded to be synonymous with P. cyanovitellosus $[17,26,27]$.

In our opinion, the genus Hydrophitrema and/or the type species $H$. giganticum should be re-assessed and validated. In the present study, our specimens had thin and elongated tubular bodies, with thin body parts between the ventral sucker and anterior testis. The ventral sucker was located at $7-12 \%$ ( $10 \%)$ of the body length and strongly developed with peduncles. The seminal vesicle was surrounded by a thick muscular layer and positioned in the anterior body, somewhat posterior to the ventral sucker. The testes were tandem in arrangement. Tegumental folds or thickening around both suckers were not observed. These features clearly satisfied the morphological characteristics of $P$. cyanovitellosus and comparisons provided by Vercammen-Grandjean et al. [20]. In addition, $P$. cyanovitellosus, observed in the picture of gross lesion at the necropsy in the present study (Fig. 1), seems well-distinguished from the pictures of the lung fluke thought to be $H$. giganticum (see Gillett et al., 2017 Fig. 8A, B) [27]. The elongate-tubular body is likely being the typical body shape of the species or even the genus, because both flexed and contracted specimens showing similar body form. Against this background, we temporarily decided to deem both species as valid in the present study.

The descriptions and drawings provided by previous literature indicate only the pulmovermins found from sea kraits belonging to the subfamily Laticaudinae, showing the morphological characteristics of $P$. cyanovitellosus as described above $[11-13,19,20]$. On the other hand, trematode parasites that have the typical morphological characteristics of $H$. giganticum were only detected in hydrophinii sea snakes [18-20,22-23,27]. In our case, the parasites shared a laticaudinii definitive host, $L$. semifasciata, with previous reports of $P$. cyanovitellosus. The host differences between P. cyanovitellosus and H. giganticum were thought to be one of the important factors differentiating their 
genuine taxonomic status.

Pulmovermis cyanovitellosus was first reported by Coil and Kuntz [11] from the lungs of L. semifasciata located off the coast of Yeh Yu, the west coast of Lan Yu Island in Taiwan. Six years later, Telford [12] investigated the parasites of $L$. semifasciata located off Amami Island, Japan, and found a species of lung fluke. Because he overlooked the publication of Coil and Kuntz [11] during preparation of his study, he named his specimens as Laticaudatrema amamiensis. Telford [28] later realized, and regarded his species synonymous to P. cyanovitellosus. Further studies revealed the additional distribution sites of this species, i.e., Ishigaki Island and Kudaka Island, Japan [13,29]. The present case is the fifth and northernmost report of the species.

In 1933, Yamaguti examined the common sea krait Laticauda laticauda, from Ishigaki Island, Japan, and found 3 specimens of digenean flukes in the small intestines. He placed his specimens under the genus Harmotrema Nicoll, 1914, and reported the species as a new species, namely Harmotrema laticaudae [30]. An additional report was conducted by Telford [12] off Amami Island, Japan. He found 10 infected snakes out of $51 \mathrm{~L}$. semifasciata. He noted his specimens agreed well with H. laticaudae, but he did not leave any detailed morphological descriptions except for a picture. Additional host and location data of this species was obtained by Brooks et al. [31], off Australia. The morphological characteristics and morphometric data of the present specimens $(n=4)$ are well-fitted to the data provided by Yamaguti [30], except for certain characteristics, for example all the specimens had inverted cirri in the present study. In Yamaguti's description, the vitelline follicles were distributed to the posterior margin of the ventral suckers, and he mentioned the vitelline follicles extending from the ventral sucker zone [30]. In our specimens, depends on the specimen, the vitelline follicles were distributed to the posterior margin of the ventral sucker or extended with some distance from posterior margin of ventral sucker. Thus, the anterior distribution of the vitelline follicles does not appear to have high taxonomic value.

Conclusively, we collected 2 digenean trematode species from a Chinese sea snake, L. semifasciata, which was caught offshore of Jeju Island, Korea. Based on morphological identification, we identified the worms as P. cyanovitellosus and $H$. laticaudae, and both species have not been previously reported in Korean parasitic fauna. We newly detailed and recorded their morphological descriptions. The taxonomic status of the genera Pulmovermis and Hydrophitrema were also discussed based on a comparison between the information obtained in the present study and previous literature. The differences between the 2 genera were re-verified, and we provided new insight in terms of host ranges. However, the taxonomic value remains questionable and further research is required; our observations were restricted to a group of parasites found within a host without comparisons to genuine specimens collected from hydrophinii sea snakes. The results of this study should be corroborated with additional observations of specimens collected from both hydrophinii and laticaudinii sea snakes. Additional studies, including DNA analyses, will be helpful in confirming taxonomic status and provide further insight into the likely ecology of parasites in Korea.

\section{ACKNOWLEDGMENTS}

This work was supported by a grant from the National Institute of Biological Resources (NIBR), which is funded by the Ministry of Environment (MOE) of the Republic of Korea (NIBR no. 2019-02-001) and the Parasite Resource Bank of Korea of the National Research Resource Center (20120000037) of the Republic of Korea. This study was supported by grants from the National Marine Biodiversity Institute of Korea (2020M00300).

\section{CONFLICT OF INTEREST}

The authors declare that they have no conflicts of interest regarding the publication of this article.

\section{REFERENCES}

1. Gorman GC. The chromosomes of Laticauda and a review of karyotypic evolution in the Elapidae. J Herpetol 1981; 15: 225233.

2. Slowinski JB, Knight A, Rooney AP. Inferring species trees from gene trees: a phylogenetic analysis of the Elapidae (Serpentes) based on the amino acid sequences of venom proteins. Mol Phylogenet Evol 1997; 8: 349-362.

3. Scanlon JD, Lee MSY. Phylogeny of Australasian venomous snakes (Colubroidea, Elapidae, Hydrophiinae) based on phenotypic and molecular evidence. Zool Scr 2004; 33: 335-366.

4. Sanders KL, Lee MSY, Leys R, Foster R, Keogh JS. Molecular phylogeny and divergence dates for Australasian elapids and sea snakes (Hydrophiinae): evidence from seven genes for rapid evolutionary radiations. J Evol Biol 2008; 21: 682-695. 
5. Kim IH, Park J, Suk HY, Bae HG, Min MS, Tasi TS, Park D. Phylogenetic relationships of three representative sea krait species (genus Laticauda; elapidae; serpentes) based on 13 mitochondrial genes. Mitochondrial DNA A DNA Mapp Seq Anal 2018; 29: 772-777.

6. Park J, Kim IH, Koo KS. Park D. First record of Laticauda semifasciata (Reptilia: Squamata: Elapidae: Laticaudinae) from Korea. Anim Syst Evol Divers 2016; 32: 148-152.

7. Heatwole H. Sea Snakes. Sydney, Australia. University of New South Wales Press. 1999, pp 1-148.

8. Kharin VE. Redescription of a Russian finding of the erabu sea krait Pseudolaticauda semifasciata (Reinwardt in Schlegel, 1837), with remarks about species composition of sea snakes (Serpentes: Laticaudidae, Hydrophiidae) in Russian and adjacent waters. Russ J Mar Biol 2009; 35: 8-14.

9. Tandavanitj N, Mitani S, Toda M. Origins of Laticauda laticaudata and Laticauda semifasciata (Elapidae: Laticaudinae) individuals collected from the main islands of Japan as inferred from molecular data. Curr Herpetol 2013; 32:135-141.

10. Park J, Kim IH, Fong JJ, Koo KS, Choi WJ, Tasi TS, Park D. Northward dispersal of sea kraits (Laticauda semifasciata) beyond their typical range. PLoS One 2017; 12: e0179871.

11. Coil WH, Kuntz RE. Three new genera of trematodes from Pacific sea serpents, Laticauda colubrina and L. semifasciata. Proc Helminthol Soc Wash 1960; 27: 147-150.

12. Telford SR Jr. Studies on the parasites of oriental reptiles I. Parasitology of the seasnake, Laticauda semifasciata, in the vicinity of Amami Island, Japan. Jpn J Exp Med 1967; 37: 245-256.

13. Ohashi T, Ohtawa T, Asakawa M. A record of two species of internal parasites obtained from lungs of sea snakes (Laticauda semifascitata) collected in Okinawa Prefecture, Japan. J Rakuno Gakuten Univ 2017; 42: 179-181 (in Japanese).

14. Park J, Koo KS, Kim IH, Choi WJ, Park D. First record of the blue-banded sea krait (Laticauda laticaudata, Reptilia: Squamata: Elapidae: Laticaudinae) on Jeju Island, South Korea. Asian Herp Res 2017; 8: 131-136.

15. Gordon L. Blame El Niño for poisons sea snake found on Ventura County Beach [Internet]; [cited 2019 Oct 3]. Available from: https://www.latimes.com/local/lanow/la-me-ln-venomous-seasnake-found-20151016-story.html.

16. Heatwole H, Lillywhite H, Grech A. Physiological, ecological, and behavioral correlates of the size of the geographic ranges of sea kraits (Laticauda: Elapidae, Serpentes): A critique. J Sea Res. 2016; 115: 18-25.

17. WoRMS. 2019. Hydrophitrema giganticum Sandars, 1960 [Internet]; [cited 2019 Oct 3]. Available from: http://www.marinespecies.org/aphia.php?p=taxdetails\&id=843494.
18. Sandars DF. Hydrophitrema gigantica, n. gen. n. sp. (Trematoda, Digenea) from Hydrophis elegans (Gray, 1842) from Australia. Sobretiro del libro Homenaje al Doctor Eduardo Caballero y Caballero, 1960, pp 263-268.

19. Sandars DF. Hydrophitrema gigantica, n. gen., n. sp. (Trematoda, Digenea) from Hydrophis elegans (Gray, 1842) from Australia. In Caballero EC, de Ciencias Biológicas EN eds, Libro Homenaje al Dr Eduardo Caballero y Caballero, Jubileo 1930-1960. Mexico City, Mexico. Secretaria de educacion publica. 1960, pp 263268.

20. Vercammen-Grandjean PH, Heyneman D. Pulmovermis and $H y$ drophitrema, hemiurid lung flukes of sea snakes: new host records with a corrigendum and reevaluation. J Helminthol 1964; 38: 369-382.

21. Coil WH. Observations on egg shell formation in Hydrophitrema gigantica Sandars, 1960 (Hemiuridae: Digenea). Z Parasitenkd 1965; 25: 510-517.

22. Madhavi R, Rao KH. Record of Hydrophitrema gigantica Sandars, 1960 (Trematoda: Hemiuridae) from sea snakes of Waltair coast, Bay of Bengal. Curr Sci 1973; 12: 425-427.

23. Ko RC, Lance V, Duggan RT. Note on biology of Hydrophitrema gigantica Sandars, 1960 (Trematoda: Hemiuridae) from the lung of sea snakes (Hydrophis cyanocintus). Can J Zool 1975; 53: 1181-1184.

24. Gibson DI, Bray RA. The Hemiuroidea: terminology, systematics and evolution. Bull Br Mus Nat Hist (Zool) 1979; 36: 35-146.

25. Gibson DI. Hemiuridae looss, 1899. In Gibson DI, Jones A, Bray RA ed, Keys to the Trematoda. Vol 1. London, UK. CABI International and The Natural History Museum. 2002, pp 305-340.

26. Lauckner G. Diseases of reptilia. In Kinne O ed, Diseases of Marine Animals. Hamburg, Germany. Biologische Anstalt Helgoland. 1983, pp 553-626.

27. Gillett AK, Ploeg R, Flint M, Mills PC. Postmortem examination of Australian sea snakes (Hydrophiinae): Anatomy and common pathologic conditions. J Vet Diagn Invest 2017; 29: 593-611.

28. Telford SR. Laticaudatrema amamiensis Telford, 1967, a junior synonym of Pulmovermis cyanovitellosus Coil and Kuntz, 1960. J Parasitol 1970; 56: 430.

29. Sokolov SG, Atopkin DM, Urabe M, Gordeev II. Phylogenetic analysis of the superfamily Hemiuroidea (Plathelminthes, Neodermata: Trematoda) based on partial $28 \mathrm{~S}$ rDNA sequences. Parasitology 2019; 146: 596-603.

30. Yamaguti S. Studies on the helminth fauna of Japan. Part 1. Trematodes of birds, reptiles and mammals. Jpn J Zool 1933; 5: 86-91.

31. Brooks DR, Overstreet RM. The family liolopidae (Digenea) including a new genus and two new species from crocodilians. Int J Parasitol 1978; 8: 267-273. 
